\title{
IMAGINARIO DEL INDÍGENA CHIQUITANO. VISIBILIDADES Y OCULTAMIENTOS
}

\section{Mariana Giordano}

La intención de este trabajo es analizar la construcción de un universo imaginario sobre el indígena chiquitano, a través del análisis complementario de textos escritos y visuales. Si bien nos centraremos en imágenes producidas luego de los procesos de independencia americanos en los siglos XIX y la primera mitad del siglo XX, consideramos también el imaginario colonial, a los efectos de establecer relaciones y paralelismos posibles y de evidenciar el carácter dinámico del imaginario.

Los textos visuales y escritos que analizamos pertenecen a diferentes emisores, (misioneros, viajeros, funcionarios, fotógrafos), producidos en la región de Chiquitos, donde las Misiones Jesuíticas de la Chiquitanía o "Provincia de Chiquitos" congregaron diversas etnias (las principales fueron las familias lingüísticas chiquitana, arawaka y chapacura, aunque también hubo guaraníes y zamucos) ${ }^{2}$ dándoles "unidad" y adoptando la lengua chiquita como elemento unificador. Dependiente del Provincial del Paraguay (Provincia Paracuaria), se vincula entonces a esta región en función de un proyecto misionero común, y por una dependencia jerárquica que obligaba a una comunicación entre ambas para la cual el Chaco - una tercera región fronteriza- cumplía una posición espacial estratégica.

En la actualidad, la imagen de la Chiquitanía que se difunde, la presenta como una zona selvática donde el circuito misional se caracteriza por la imponencia de las antiguas iglesias jesuíticas y la ruta de la Chiquitanía perfila precisamente ese patrimonio. Por su parte, la población indígena se difumina, se silencia, se invisibiliza en primacía del patrimonio arquitectónico y natural de la región. Ésta invisibilidad del indígena ha sido uno de los factores que nos llevaron a tomar este espacio para continuar nuestras investigaciones referidas a las representaciones de los pueblos originarios que hemos realizado para la región chaqueña.

A modo de hipótesis, afirmamos que el "indígena chiquitano evangelizado" se erige en el núcleo del imaginario colonial del universo jesuítico, a modo de imagen paradigmática.

\footnotetext{
${ }^{1}$ Esta región ubicada hoy en Bolivia se fue configurando y reformulando desde la llegada de los españoles y la experiencia misional jesuítica (1691-1767) le otorgó una unidad espacial-geográfica. En la actualidad se suele hacer referencia a ella como un ámbito ubicado en el oriente boliviano que limita al sur con el Chaco, al este con el río Paraguay, que lo separa del Matto Grosso, al oeste se extiende hasta río Grande o Guapay y al Norte $15^{\circ}$ lat. O. A nivel político dicha región comprende, actualmente, a cinco provincias del departamento de Santa Cruz de la Sierra.

${ }^{2}$ Véase al respecto Roberto Tomichá Charupá. La primera evangelización en la Reducción de Chiquitos, Bolivia (1691-1767). Protagonistas y Metodología misional. Roma, Pontificia universitas Gregoriana, 2000, pp. 145186.
} 
Con la expulsión de la Compañía de Jesús y la disgregación y dispersión de los grupos indígenas misioneros, esta imagen persistió en el imaginario social, y se encuentra presente en muchas percepciones actuales que han permeado en los discursos y proyectos políticos y religiosos. Sin embargo, esta imagen genérica presenta escasa relación con la situación que vivieron los grupos indígenas tras su dispersión y las diferentes actitudes asumidas por la República boliviana que se conformó posteriormente sobre el área de las antiguas misiones jesuíticas de chiquitanos.

\section{Imaginarios, imágenes y construcción de alteridades}

Al hablar de "imaginario", nos referimos a las imágenes o representaciones que nos hacemos de una cosa u objeto en nuestra mente, ya sea a partir de paquetes textuales escritos o visuales. Estas imágenes están vinculadas con la "producción de sentido" que construimos y atribuimos individual o colectivamente a la realidad, y por ello está mediatizada por la cultura, la ideología, los valores y las percepciones del grupo social emisor de los discursos.

Esta producción de sentido constituye así "la parte ideal de lo real", lo que nos permite vincular el discurso, las representaciones y el imaginario: las imágenes que componen el imaginario establecen el significante que instaura un orden simbólico que no existe en la realidad y que "se teje" en redes de relación de sentido, en sistemas de significación que conforman una imagen del mundo, que llega posteriormente a institucionalizarse socialmente.

A su vez, la construcción y sostenimiento de imaginarios sociales se produce en contextos geopolíticos particulares, que con el paso del tiempo tienden a anclarlos y a establecerlos como permanentes y homogéneos, cuando en su interior muchas veces se perfilan grietas, pliegues y resignificaciones.

En el caso que nos ocupa -los imaginarios vinculados a los procesos de construcción de identidades del indígena chiquitano- suelen ser los que comúnmente tienden a homogeneizar y uniformizar las relaciones sociales y los aspectos culturales en un área acotada, demarcando así "lo regional", en detrimento de lo diverso y múltiple de las vinculaciones entre regiones.

$\mathrm{Al}$ referirnos al imaginario sobre el indígena chiquitano entramos en el campo de la construcción de alteridades, entendiendo la "alteridad" o la "otredad" como el "efecto" o resultado de los procesos a través de los cuales una cultura hegemónica se ha relacionado con grupos subalternos, visualizándolos y (des)calificándolos en función de sus diferencias físicas, lingüísticas, religiosas, etc.

Por su parte, la imagen visual, incluso la fotográfica, es tomada en este análisis como un "texto social" posible de ser analizado en sus significaciones históricas, estéticas e ideológicas. Aquello que para su emisor pudo ser tomado como "testimonio", hoy también puede ser considerarlo desde el punto de vista estético y como reflejo de una concepción ideológica (por ejemplo, como modo de emular o exaltar cierto elemento identitario, o como un modo de "propaganda" de un accionar determinado). Por otro lado, dado que las memorias se labran en términos identitarios es central observar con cuáles materiales, 
cuándo y cómo se modelan estas memorias y cómo se expresan en paquetes textuales (escritos y visuales). Es en este punto donde los textos visuales adquieren una importancia sobresaliente en la construcción de otredades.

Desde el punto de vista metodológico realizamos un análisis de contenido, tanto en su sustancia como en su forma: ello nos permite centrar la atención en vocablos y símbolos que configuran el contenido de las comunicaciones o discursos seleccionados ${ }^{3}$. Asimismo, analizamos las potencialidades de la imagen como estrategia discursiva por parte de los emisores de las mismas y en función de los posibles receptores a los que estaban dirigidas. Para ello nos detenemos tanto en su presencia como en su ausencia en ciertos escritos, y en lo "visto y no visto" -en términos de Peter Burke- en cada una de ellas, analizando sus contextos de producción, circulación y recepción. Así también se contemplan los paradigmas visuales imperantes en la época que actuaron de trasfondo estético a las instancias de registro y representación.

\section{Los orígenes del imaginario chiquitano: el discurso jesuítico}

Si bien los jesuitas llegaron a Santa Cruz de la Sierra en 1587 y tuvieron los primeros contactos con los chiquitanos a fines del siglo XVI, la región de Chiquitos permaneció aislada hasta un siglo después, ya que los misioneros habían trasladado su atención a los chiriguanos del Chaco boliviano. Fue recién a fines del siglo XVII cuando la Compañía de Jesús acepta la evangelización de la provincia de Chiquitos, porque al igual que sus vecinos (los grupos chaqueños), comienzan a ser vistos como una amenaza constante para las misiones ya establecidas.

Los jesuitas que instalaron las Misiones ${ }^{4}$ en la región de Chiquitos venían de casi un siglo de experiencia misionera en Paraguay, por lo que su estructura, administración y doctrina eran semejantes a las Misiones Jesuíticas de aquella región. Y al igual que en ella, el proceso evangelizador fue bastante rápido en Chiquitos, con una fuerte adaptación de la población indígena al régimen misionero.

El imaginario colonial sobre el indígena "chiquito"s se corresponde principalmente con las imágenes que los jesuitas conformaron a través de sus escritos. Fueron ellos los que le dieron unidad a un conjunto de etnias bajo el nombre globalizador de "chiquitos", la familia lingüística más numerosa que habitaba la región a la llegada de los sacerdotes.

\footnotetext{
${ }^{3}$ De esta forma podemos identificar intenciones de los comunicantes; como así también determinar temáticas sobresalientes en textos escritos y visuales; reflejar actitudes, intereses y valores de grupos de población que actúan de receptores de los discursos; analizar la corriente de información que se pretenden transmitir; entre otros aspectos.

${ }^{4}$ Las Misiones fundadas en la región de Chiquitos fueron: San Javier (1691), San Rafael (1696), San José (1697), San Juan Bautista (1699, con una refundación en 1711), San Miguel (1721), Concepción (1699, refundada en 1709), San Ignacio (1724), Santiago (1754), Santa Ana (1755), Santo Corazón (1760).

${ }^{5}$ La denominación de "chiquitos" fue la impuesta durante los siglos XVI-XVIII por los conquistadores, colonos y misioneros al grupo étnico de lengua chiquita, que en realidad tenía varios dialectos. A partir del siglo XIX comenzaron a llamarse "chiquitanos" no solamente a aquel grupo étnico al que se le otorgó una identidad común, sino también a otros grupos que habían participado del sistema reduccional y que en el proceso misional fueron adoptando la lengua chiquita. Véase sobre este tema Roberto Tomichá Charupá. La primera evangelización en la Reducción... Op. cit., pp. 152-154.
} 
De ahí que las nominaciones y valoraciones comenzaron a ser generalizantes, a extenderse a todas las etnias de la "Chiquitanía", aunque en realidad, aludían a aquellos grupos que se habían integrado al régimen misional.

Los jesuitas, como gran parte de los misioneros que trabajaron con los pueblos originarios de América, procedían de Europa con una imagen del indígena americano que integraba conceptos descalificadores en lo concerniente a la valoración cultural y hasta fisonómica, que - en la mayoría de los casos- respondían a la imagen del "buen salvaje". Es por ello que los diversos textos etnográficos que los mismos sacerdotes produjeron son acusados por parte de la historiografía de "ideológicos", pero debemos tener en cuenta que "ideológicos" no se vincula solamente con una valoración negativa sino con un sistema de ideas y preceptos determinados, que abarca tanto las miradas peyorativas como las positivas sobre un grupo o realidad social.

De esta manera, el indígena de la región de Chiquitos es distinguido entre los "bárbaros" por el jesuita Juan Patricio Fernández, no sólo por sus costumbres "salvajes", sino también por la falta de deidades: "en materia de religión son brutales totalmente y se diferencian de otros bárbaros, pues no hay nación por inculta y bárbara que sea, que no reconozca y adore alguna deidad; pero éstos no dan culto a cosa ninguna visible ni invisible, ni aún al demonio, aunque le temen..." 6

El relato de Fernández constituye una de las principales fuentes etnográficas del período jesuítico, por lo que las imágenes que de este texto se transmiten constituyen, junto a otros documentos coloniales, una fuente legitimante del imaginario colonial sobre el indígena chiquitano. Y comparando con textos del siglo XIX, es posible advertir algunos de los itinerarios en la construcción del imaginario chiquitano a la par de los proyectos evangelizadores que se iban consolidando en la región. En la lectura global de este texto se pone en evidencia el paso del "buen salvaje" al "neófito" o al "evangelizado", y al final del trayecto, la distinción entre los que permanecen en la barbarie y los que entraron en la cristiandad. En Fernández sin embargo, aún es posible distinguir las valoraciones que realiza de las etnias de lengua chiquita en relación a otras etnias de la región, e incluso hace referencia a las divisiones que a partir de la guerra sufrieron los distintos grupos.

Mientras el chiquito es para Fernández un "bárbaro" que no admite la medicina ni cree en dioses, encuentra en él un “...temperamento ígneo y vivaz más que lo ordinario en estas naciones, de buen entendimiento, amantes de lo bueno, nada inconstantes ni inclinados a lo malo, y por esto muy ajustados a los dictámenes de la razón natural, ni se hallan entre ellos aquellos vicios e inmundicias sensuales de la carne que a cada paso se ven y se lloran en otros países de gentiles ya convertidos." Estas serán las claves que encontrarán muchos misioneros para entender los éxitos evangelizadores en estas tierras, a diferencia de la actitud de los pueblos chaqueños, donde los indígenas fueron poco proclives a la evangelización.

\footnotetext{
${ }^{6}$ Juan Patricio Fernández. Relación Historial de las misiones de indios Chiquitos que en el Paraguay tienen los padres de la Compañia de Jesús (1726). Jujuy, CEIC-UNJ, 1994, p.40.

${ }^{7}$ Ibidem, p.36.
} 
Debemos tener en cuenta que el discurso de Fernández se enmarca dentro de las concepciones etnológicas del barroco, muestra aversión hacia los grupos indígenas, cree en la antropofagia y en la presencia del demonio en las conciencias de los indígenas ${ }^{8}$.

Por consiguiente, la idea del buen salvaje que entró sin mayores dificultades al mundo del cristianismo será nuclear en el imaginario sobre el indígena chiquitano desde la época colonial, y el factor fundamental que permitirá durante siglos vincular una identidad étnica conformada externamente (a través de la reunión de grupos étnicos diversos en el espacio misional y utilizando la lengua como elemento de integración y de unificación) con el cristianismo. "Durante los siglos posteriores, los descendientes de chiquitos serán conscientes con no poco orgullo de la herencia indeleble del cristianismo en la propia cultura." $"$

Otros textos interesantes de la época jesuítica son los del sacerdote alemán Martin Schmid $^{10}$, no sólo por su contenido, sino también por la difusión que tuvieron en la segunda mitad del siglo XIX. En la construcción de un imaginario sobre el indígena chiquitano nos interesa en modo especial la cuestión de la inclinación hacia la música que la mirada de Schmid le confiere. Recordemos que la música fue uno de los elementos utilizados en la evangelización como modo de "sacar el demonio" del alma de los indígenas, de rescatar la humanidad que se podía encontrar en ellos. La obra de Schmid tiene vinculación con el origen de grupos musicales en algunas misiones y la incorporación de instrumentos en las mismas, dado que él se sentía destinado a inculcar una educación musical en la cristianización: "La suerte que he tenido al haber sido mandado a estas misiones surgió ya que entiendo la música y, hasta ahora veo porque el destino divino me guió para aprender la música desde joven y lo he podido aprovechar para hacer de estos indios no sólo cristianos fieles sino también músicos. Los indios hasta la fecha todavía no conocieron ni la música como un arte ni conocieron u oyeron notas musicales." 11

Schmid estaba convencido que los indígenas tenían una inclinación natural hacia la música, y que ésta, tanto como la arquitectura religiosa y la decoración interior de las iglesias, debían ser utilizadas con fines pedagógicos.

Este pensamiento y la acción llevada adelante por Schmid remiten al imaginario del chiquitano músico, que se ha difundido a lo largo del siglo XIX junto a la obra de Schmid por el jesuita Spillman y que se reactualiza en las imágenes del siglo XX, donde el chiquitano, al igual que el mojeño, aparecen representados ejecutando instrumentos musicales en forma individual o grupal.

\footnotetext{
${ }^{8}$ Sobre la valoración del discurso de Fernández como un ejemplo del paso del barroco a la Ilustración, resultainteresante el análisis preliminar de la edición mencionada realizada por Daniel Santamaría. Ibidem, pp. 7-11.

${ }^{9}$ Tomichá Charupá. Op. cit., p. 153.

${ }^{10}$ En su trabajo misional en Chiquitos, estuvo en San Javier entre 1730 y 1740, donde instaló una escuela de música. Luego lo encontramos en San Rafael, donde comenzó con la construcción de la iglesia del pueblo, regresando a San Javier en 1749 para iniciar allí también la construcción del pueblo, trabajo que repite luego en Concepción.

${ }^{11}$ Martin Schmid. Briefe. En: Fischer, Rainald. Pater Martin Schmid SJ, 1694-1772- Seine Briefe und sein Wirken, Zug, 1988, p. 70.
} 
Música y arquitectura son, por lo tanto, dos elementos que la labor de Schmid introduce o fortalece en el mundo chiquitano y que devendrán componentes esenciales del imaginario del chiquitano evangelizado.

\section{D' Orbigny y el chiquitano evangelizado}

Son numerosísimos los trabajos que han abordado la obra de D`Orbigny en América desde diferentes perspectivas, aunque el aspecto iconográfico ha sido escasamente tratado. Las reflexiones sobre su narrativa, tanto en lo formal como en el contenido, son significativas al momento de reconstruir el imaginario sobre el indígena chiquitano que este científicoviajero construyó. En esta oportunidad no abordaremos las contribuciones científicas de este naturalista, sino que solamente tomaremos aquellos testimonios escritos y visuales referidos al indígena chiquitano.

Recordemos que los viajeros que recorrieron América, incluso aquellos que lo hicieron con una finalidad científica, en su mayoría estuvieron imbuidos del romanticismo y del estetiscismo europeos, por lo que participaron activamente en la creación de nuevas imágenes de América y las dieron a conocer a sus lectores del "Viejo Mundo" teniendo en cuenta sus expectativas y deseos. Así, la mirada de los viajeros estuvo orientada no sólo por las motivaciones más concretas de su viaje, sino también por el impacto de sus descripciones en Europa.

D'Orbigny observó otros aspectos que iban más allá de su objetivo principal de viaje como naturalista, convirtiéndose también en un observador del "otro", de los distintos pueblos originarios que se encontraban en un contexto particular durante su viaje por América: la formación de los distintos Estados Nacionales.

D'Orbigny llegó a Bolivia en 1830, cinco años después de la independencia. Cuando en 1831 recorrió la Chiquitanía, las Misiones se encontraban en el contexto de la nueva República y su situación no era promisoria, ya que venían de atravesar la etapa que siguió a la expulsión de la Compañía de Jesús. Este compleja transición es explicada por Fischermann de esta forma: "La mala administración y el maltrato caracterizaron el período postjesuítico inmediatamente anterior, cuando ejercieron el control del territorio curas y gobernadores establecidos por la Corona de España. En este nuevo periodo, aunque mejoró en algo la situación, continuó la decadencia económica y el despoblamiento de las ex reducciones $(. . .)^{\prime \prime 12}$

En su recorrido por la región, D'Orbigny realiza una descripción tanto de la fisonomía, vestimenta y costumbres de los chiquitanos como las ceremonias religiosas en las antiguas misiones, constituyendo estos aspectos, importantes aportes a la etnología y la historia. A su llegada a la primera Misión que visitó, San Javier, nos da una semblanza del estereotipo de chiquitano que él percibe y que plasma también de forma visual:

"(de) estatura elevada los indios: fuertes, robustos, de rostro interesante, sin

\footnotetext{
${ }^{12}$ Bernd Fischermann. "Camba-Paico: la Chiquitanía en la Época Republicana”. En: Pedro Querejazu. Las Misiones Jesuíticas de Chiquitos. La Paz, Fundación BHN, 1995, p. 387.
} 
ser bello; su nariz es corta, un poco ancha; sus ojos, horizontales y el mentón rara vez muestra vestigios de la barba. Llevan la ropa de los campesinos de Santa Cruz; tienen un calzón de algodón, camisa y la cabeza descubierta, con los cabellos que caen sobre los hombros. Las mujeres, bastante poco agraciadas sin ser feas, usan el tipoi y la cabellera suelta..."13

Una cuestión interesante es el contexto en que D‘Orbigny declara hacer esta observación: se ubica a la salida de la Iglesia de San Javier, porque considera que es más fácil observar el conjunto de la población de esta forma. Consideramos importante este aspecto por dos cuestiones: en primer lugar porque vincula en forma directa al indígena chiquitano con el indígena evangelizado. Si sabemos que en momentos de la presencia jesuítica en Chiquitanía era solo una porción de la población la que se había incorporado al régimen misional, no podríamos aseverar que el chiquitano que concurría a la iglesia era representativo de todos los grupos étnicos de la Chiquitanía y que su vestimenta era la propia de los indígenas de la región. En segundo lugar porque brinda una cuestión metodológica de interés en la imagen que construye del indígena chiquitano: da a la observación un carácter irrefutable, y acude a la noción de "tipo" como "medida-humana" que la antropología utilizará en la segunda mitad del siglo XIX y que se visibilizará a través de la fotografía antropométrica. Ello contribuye a fundamentar varias afirmaciones sobre el indígena americano que tienen su origen colonial y que se reactualizan a lo largo del siglo XIX: "visto un indio, visto todos", y para el caso específico del indígena de Chiquitanía, "indio chiquitano, indio evangelizado". Incluso los numerosos elementos etnográficos que observa y narra están vinculados a la religión o al sincretismo religioso, haciendo referencia permanente a la labor y enseñanza de los jesuitas.

Cuando se refiere a otras misiones de la Chiquitanía, da por sentada la fisonomía y el carácter religioso de los indígenas, y se preocupa por describir el entorno, las ceremonias y rituales que constituyen un importante aporte a la etnología. Pero principalmente, la majestuosidad del entorno natural y de los templos es lo que determina el centro de las imágenes que su texto escrito reconstruye.

Si comparamos el afán descriptivo del texto escrito con algunas de las láminas de su Atlas de Viaje, se advierte el interés documental-descriptivo más que el afán por dramatizar las experiencias de viaje, como ocurría con otra vertiente de la literatura de viajes. La imagen funciona como complemento y legitimación del texto escrito, y como la mayoría de los viajeros del siglo XIX, se orienta a una descripción visual de los elementos mencionados en el texto escrito ${ }^{14}$. Es una iconografía de corte documental-realista que se propone por ello como objetiva: los cuerpos y rostros pierden identidad para convertirse en

${ }^{13}$ Alcides D'Orbigny. Viaje a la América Meridional. Buenos Aires, Editorial Futuro, 1945, Tomo III, p. 1148.

${ }^{14}$ Elizabeth Edwards considera que en la relación texto escrito-fotografía pueden darse varias relaciones en el significado: las imágenes pueden estar sugeridas o guiadas por el texto; o pueden ser legitimadas en el dominio científico o disciplinar a través del texto; una leyenda puede conferir inmediatismo y convicción a las fotografías; o el texto puede tener una función amplificadora de la imagen. Elizabeth Edwards. Anthropology \& Photography. 1860-1920. London, Yale University Press, 1992. Estas consideraciones pueden aplicarse a estas imágenes con interés narrativo-documental, que constituyen un antecedente de las funciones antropológicas la fotografia. 
tipos representativos de un universo y la imagen se exime de una valoración de tipo social o moral de los retratados. El interés se centra en la visibilización de las vestimentas, accesorios y algunos objetos que son también descriptos en el texto escrito. Ellos se convertirían en actos de iconicidad, en señas de referencia étnica. Los índices del "chiquitano" en los dibujos de D'Orbigny son el tipoy con cintas de colores bordadas en las mujeres y los calzones de algodón para los hombres, tal como expresaba en su narrativa. La diferencia del largo de la cabellera también se expresa en el discurso escrito y visual, lo cual responde a la condición de soltero o casado del hombre. Entre los accesorios, las mujeres sostienen tinajas y los hombres una varilla, a la vez que ambos llevan colgados una cruz en el pecho. El templo ha sido visibilizado a través de esta cruz, que constituye el símbolo visual más inequívoco del chiquitano evangelizado. (Imagen 1)

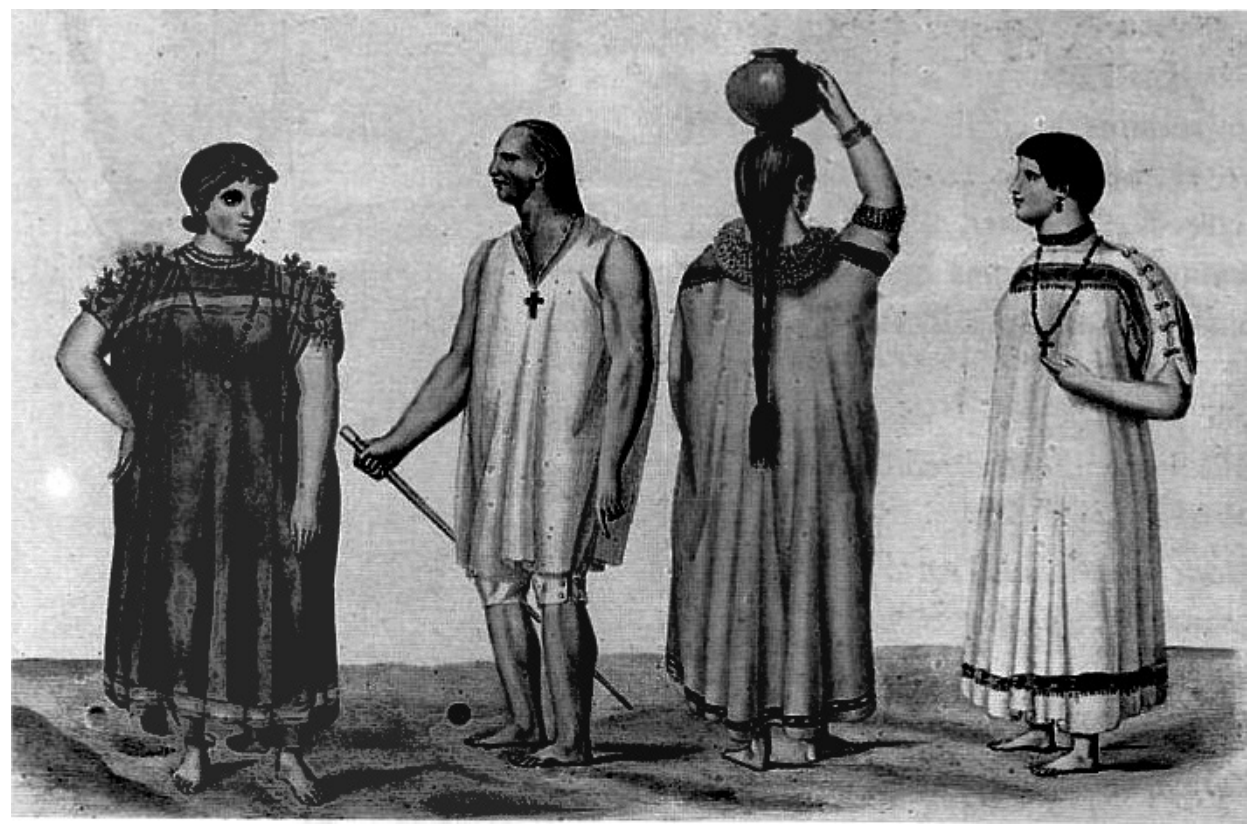

Imagen 1. Alcides D'Orbigny. "Indias e indios de la Provincia de Chiquitos" En: Viaje a la América Meridional

Si bien son recursos estandarizados los que se utilizan en la representación del chiquitano en estos dibujos, muchas de las representaciones femeninas emulan las poses de las esculturas helénicas. El desnudo, tan difundido en la representación del indígena, no aparece en el caso chiquitano, y ello también tiene vinculación con la equivalencia chiquitano=evangelizado. Ya que el desnudo fue perseguido por los misioneros y por ello las normas del vestir estaban pautadas en la vida de la misión.

En las vistas de las Misiones selecciona la plaza, porque en ella se visibilizaba la iglesia, la torre-campanario y las capillas-posas que cumplían funciones para la catequesis 
y las fiestas religiosas. De hecho, "las plazas contaban con los elementos que permitían el sentido de sacralización de las actividades cotidianas en concordancia con las modalidades de uso y los valores simbólicos que presidían el proyecto misionero." ${ }^{15}$ Pero D'Orbigny también enmarca la plaza en un escenario natural más amplio, que vincula al concepto que tanto se explotará en la actualidad: aquel que hace referencia a la "esplendorosa Chiquitanía". En la vista de la plaza de la Misión San José, un segundo plano nos revela un paraíso natural extraordinario; a la vez que a través de la utilización de una línea de horizonte medio logra remarcar la noción de inconmensurabilidad. Naturaleza exuberante y edificios paradigmáticos del arte barroco misionero son algunos de los ejes de su discurso. Entorno natural y construido con el que se mimetiza al indígena. (Imagen 2).

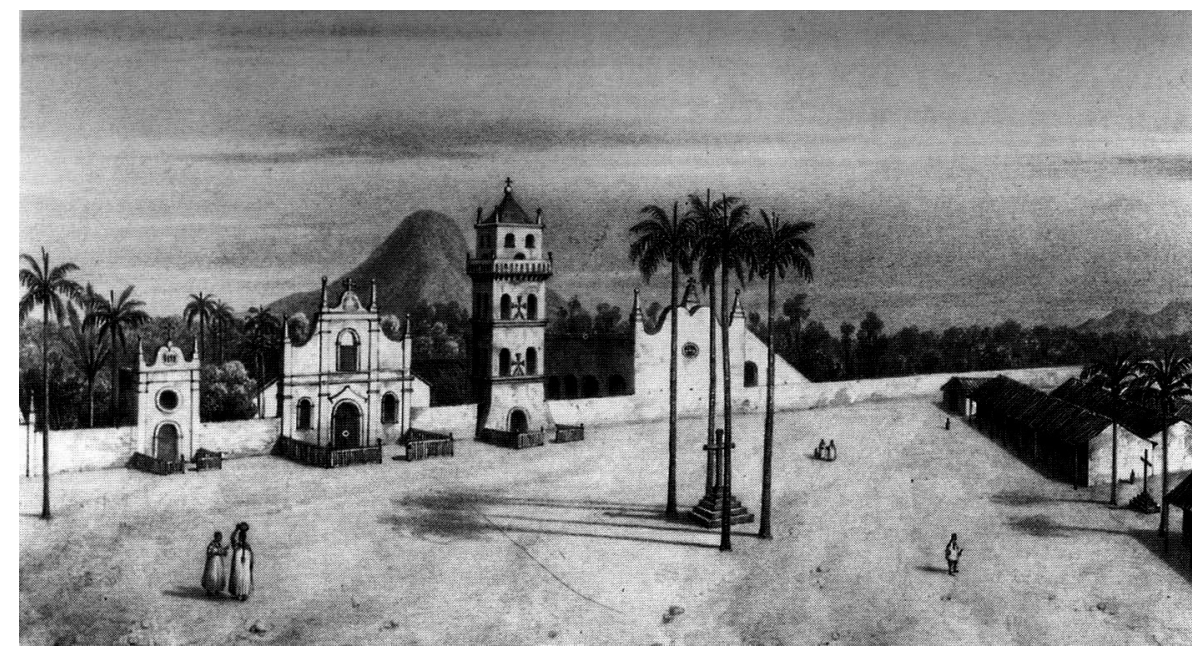

Imagen 2. Alcides D’Orbigny. "Vista de la plaza de San José, Misiones Jesuíticas, en la Provincia de Chiquitos (Bolivia)"

En: Viaje a la América Meridional

Pensemos en la circulación de estas imágenes: ellas no sólo se convirtieron en las ilustraciones de los textos de D'Orbigny y por lo tanto tuvieron una amplia circulación en el ámbito académico, sino que la revista Le Tour du monde ${ }^{16}$ que publicó la primera edición de su viaje, reprodujo varios de los dibujos llegando así a ser apreciadas por un público más amplio. Público que también formó una imagen del indígena chiquitano sobre las representaciones visuales y escritas de D'Orbigny.

En síntesis, D'Orbigny transmite un imaginario del indígena chiquitano vinculado al orden misionero -aunque los jesuitas habían abandonado las misiones en 1767- e integrado

15 Ramón Gutiérrez y Rodrigo Gutiérrez Viñuales. "Territorio, urbanismo y arquitectura en Moxos y Chiquitos". En: Pedro Querejazu (ed.). Las Misiones Jesuíticas de Chiquitos. Op. cit., , p.341.

16 "Le Tour du Monde" fue la pionera de las revistas de viaje. Dirigida por Edouard Charton, se editó en Paris entre 1860 y 1914 con una periodicidad semestral. Las ilustraciones y grabados de esta revista tuvieron una gran popularidad y difusión. 
a una naturaleza prodigiosa y a un entorno construido al que el registro visual parecería referir de manera "evidente".

\section{Pliegues en los imaginarios regionales: Melchor María Mercado}

Una década después de las representaciones de D'Orbigny, nos encontramos con otro conjunto iconográfico de gran interés en la representación de los tipos sociales bolivianos, y en lo que nos compete en este trabajo, del mundo chiquitano. Se trata del Album de paisajes, tipos humanos y costumbres de Bolivia (1841-1869) ${ }^{17}$ de Melchor María Mercado ${ }^{18}$.

En el texto escrito, Mercado coincide en varios aspectos con D'Orbigny -de quien conocía sus escritos e imágenes- en la descripción del indígena chiquitano. En relación a chiquitanos que ha encontrado en la región de San José, expresa:

"Son por lo común de mala fisonomía, de color cobruno, muy francos y obsequiosos, pero sumamente pobres, y todos sus bienes consisten en una hamaca y flecha, siendo raro el que posee un hacha u otra herramienta de hierro.

Los hombres casados usan pantalón y chaqueta, los solteros sólo pantalón y una especie de poncho de lienzo muy angosto que sirve también de camisa...

Las mujeres son generalmente feas, visten un tipoy, o túnica larga, precisamente blanca, con algunos bordados de lana punzó y amarillo en rededor del pecho y del vuelo bajo; sus adornos son chaquiras que se ponen indistintamente en hilos o manojos ... Llevan por la mañana al amanecer, que se dirigen precisamente al templo, el pelo suelto caído a ambos lados de la cabeza, y sólo después de esta obligación religiosa se hacen el peinado, que es el común partido en dos trenzas gruesas.

Las solteras tienen el pelo corto y tan redondeado como un cerquillo de fraile, siendo éste el distintivo entre solteras y casadas..." 19

\footnotetext{
${ }^{17}$ Melchor María Mercado. Album de paisajes, tipos humanos y costumbres de Bolivia (1841-1869). Banco Nacional de Bolivia, Sucre, 1983.

${ }^{18}$ Nacido en Sucre en 1816 en una familia de clase media criolla, estudió leyes, se dedicó a la política, fue pintor, músico y aficionado a las ciencias de la naturaleza. Las obras que integran su Álbum fueron pintadas durante sus largas deportaciones como prisionero político al interior del territorio boliviano. Un análisis interesante sobre las mismas se encuentra en Silvia Rivera Cusicanqui. Invisible Realities: internal markets and subaltern identities in Contemporary Bolivia. Malasia, Vinlin Press Sdn Bhd, 2005. El texto introductorio de la publicación de su Álbum, realizado por Gunnar Mendoza L. también presenta un análisis del contexto de interés para el análisis de su obra.

${ }_{19}$ Melchor María Mercado. Álbum de paisajes, tipos humanos... Op. cit., p. 223.
} 
Esta narración se complementa de modo perfecto con las imágenes de D’Orbigny y del mismo Mercado cuando representa los indígenas de Mojos, lo que revela la uniformidad en el vestido y el peinado impuesto por el régimen misional. (Imagen 3).

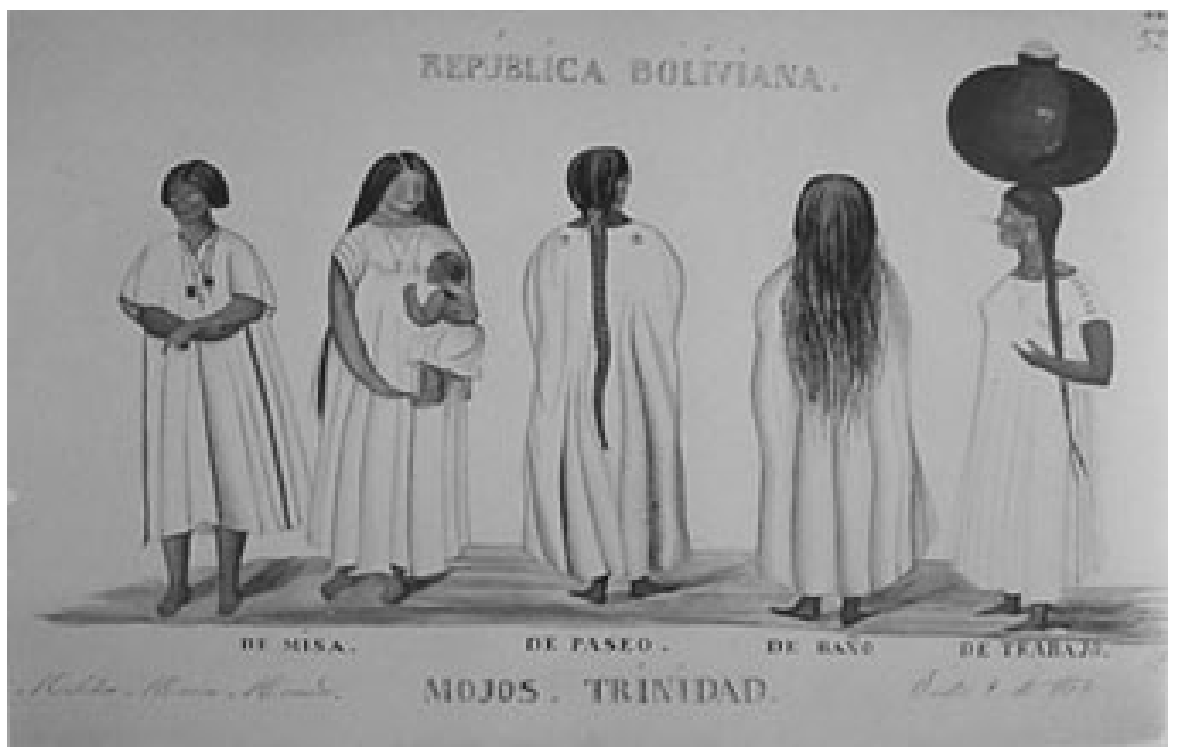

Imagen 3. Melchor María Mercado. "República boliviana. Mojos. Trinidad" Álbum de paisajes, tipos humanos y costumbres de Bolivia (1841-1869)

Si tomamos el universo visual de Mercado, sus imágenes responden a una visión crítica de la realidad boliviana de su época y, aunque fueran catalogadas en muchos trabajos como una continuación de las representaciones de D'Orbigny, se apartan de aquellas en varios aspectos, como veremos al analizar el caso chiquitano.

Mercado no hace un mero muestreo de tipos sociales, sino que “... los gestos, costumbres y caracteres de los tipos humanos descritos en el Álbum también dan una rica información de las fronteras y etiquetas étnicas, como así también de la proliferación de mezclas en los tipos y de las fronteras que el mercado les permitía."

Si bien abundan las imágenes de la región de Mojos, superiores en comparación con las de Chiquitos, en algunas representaciones de éste último retoma las representaciones de D'Orbigny. Pero a diferencia de D'Orbigny en Mercado aparece un elemento sustancial que era inexistente en el naturalista francés: mujeres bañándose desnudas (Imagen 4). Esta temática se convierte en una imagen diferencial respecto de la imagen del chiquitano evangelizado: recordemos que los jesuitas como los franciscanos lucharon en sus misiones contra el desnudo indígena, y que normaron las formas de vestir y hasta de peinarse de las indígenas (esto lo representa Mercado en la Imagen 3 de indígenas de Mojos, donde la 
etiqueta señala: “de misa", “de paseo", “de baño", “de trabajo", etc.). Por ello, las imágenes con desnudos rompen con la representación homogénea del indígena chiquitano evangelizado, o constituyen pliegues representacionales que difieren de su imagen generalizada.

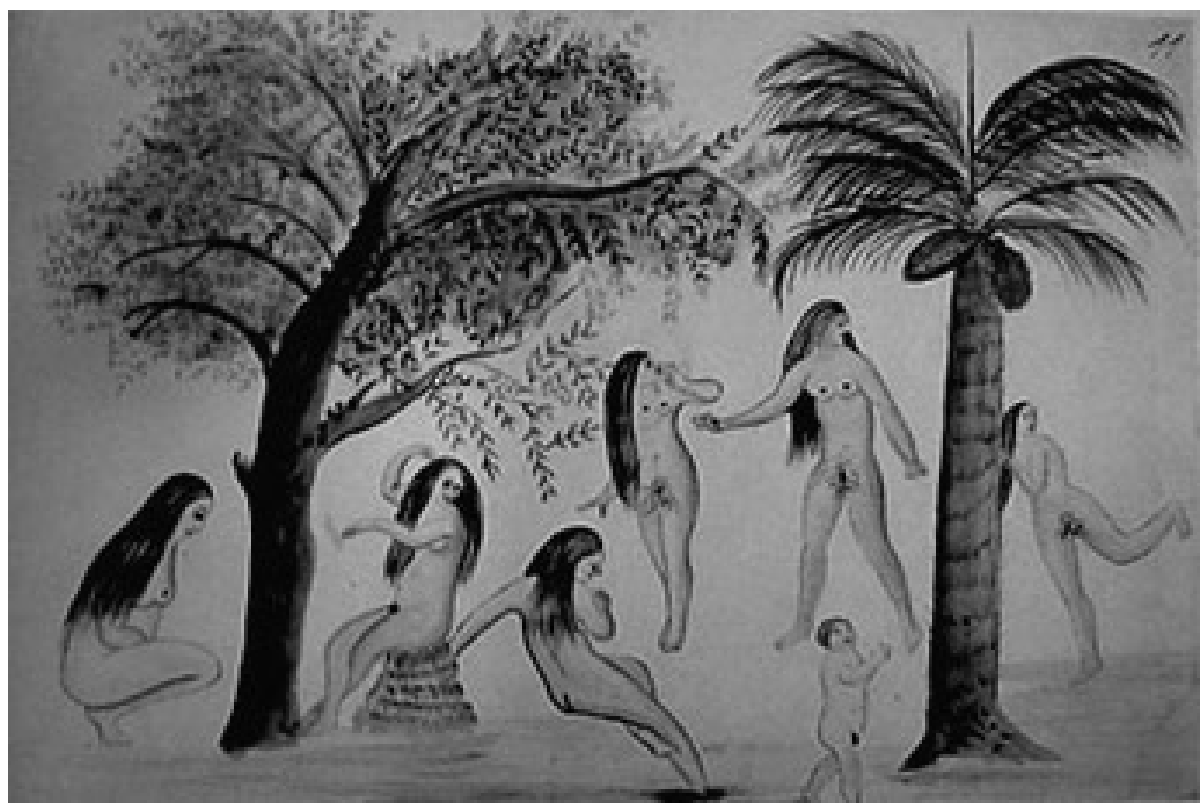

Imagen 4. Melchor María Mercado. "Mujeres tomándose un baño. Área oriental de Bolivia." Álbum de paisajes, tipos humanos y costumbres de Bolivia (1841-1869)

Las imágenes de Mercado no son productos de su fantasía, sino que tiene una mirada que en oportunidades no se limita a una descripción naturalista como lo hiciera D' Orbigny, sino que sin ninguna traba académica, se expresa con mayor libertad y no se limita a las representaciones de pose y a las convenciones gestuales. Lo que hace que los distintos grupos sociales a los que se refiere y que visibiliza asuman un carácter en ocasiones ingenuo ${ }^{21}$ y en otras alegórico. Pero esa ingenuidad no es acrítica, sino comprometida y sutil, ya que vistas en su conjunto hacen referencia a las relaciones y contrastes de clases, visibiliza a dominantes y dominados, y entre los primeros hace referencia a la injusticia de las instituciones, muchas de ellas de raigambre colonial.

Por otro lado, la representación de grupos bororos (que en el imaginario social y académico siempre estuvieron vinculados al Brasil), pone de manifiesto el tema de las fronteras étnicas y las fronteras nacionales: en la Chiquitanía no aparecían los bororos como

\footnotetext{
${ }^{21}$ Mendoza señala que Mercado “... dibuja y pinta como un niño, en el sentido de que no le interesa la perfección sino la representación de lo que ve como él lo ve y como puede expresarlo”. Ibidem, pp. 42-43. Podríamos acordar con este autor en la ingenuidad del niño en cuanto al antiacademicismo, pero no en relación a la lectura que hace Mercado de aquello que representa.
} 
habitantes propios de esa región, y Mercado los introduce en sus referencias visuales del oriente boliviano, poniendo en juego las relaciones del Matto Grosso con la Chiquitanía, y los grupos indígenas que en ambas se representan (Imagen 5).

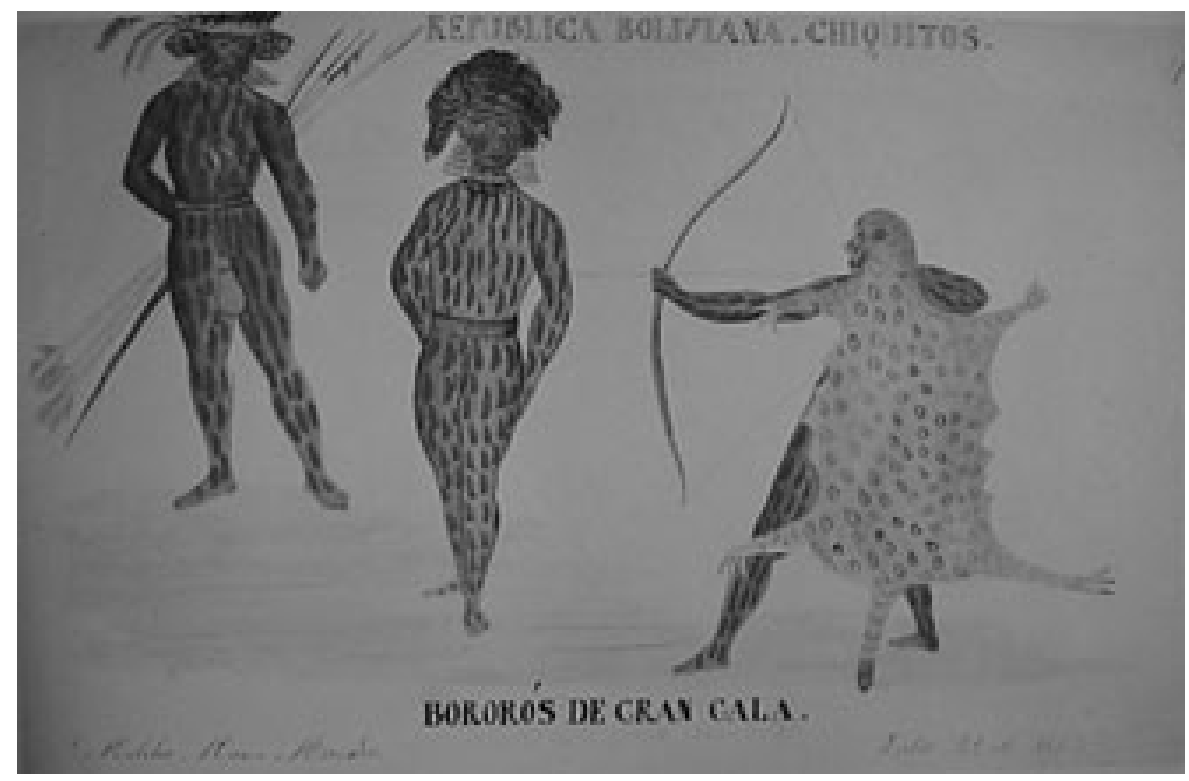

Imagen 5. Melchor María Mercado. "República boliviana. Chiquitos. Bororós de Gran gala." Álbum de paisajes, tipos humanos y costumbres de Bolivia (1841-1869)

Rivera Cusicanqui manifiesta que la mirada de Mercado sobre una Nación posible y los límites impuestos por el legado colonial y las instituciones políticas y jurídicas que se perciben en sus textos e imágenes, hacen que se oponga a gran parte de la historiografía contemporánea ${ }^{22}$. Esta aseveración referida al álbum en su conjunto, creemos que se hace evidente para las imágenes de la Chiquitos en los dos aspectos antes señalados: la presencia del desnudo y de otros grupos indígenas que la historiografía tradicional no vinculaba a esta región. Mendoza ha señalado que las láminas de Melchor María constituyen un trabajo "único en su género, de integración nacional en el ámbito del arte"²3. Nosotros consideramos, por el contrario, que Mercado pone en evidencia las múltiples identidades que constituyen su país, no busca representar "una" identidad nacional, sino poner en evidencia las múltiples realidades existentes. Al decir de Rivera Cusicanqui, distingue la "Nación política" de la "Nación real", aquella en la que las contradicciones, lo diverso, lo plural, también en la Chiquitanía, participan del juego de las representaciones.

${ }^{22}$ Rivera Cusicanqui. Op. cit., p. 16.

${ }^{23}$ Gunnar Mendoza L. "Vocación de arte y drama histórico nacional en Bolivia: el pintor Melchor María Mercado (1816-1871). Un precursor". En: Melchor María Mercado. Álbum de paisajes, tipos humanos y costumbres de Bolivia (1841-1869). Análisis preliminar a la edición. Op. cit., p.42. 
En cuanto a las vistas urbanas y los registros arquitectónicos de Mercado, siguen la línea marcada por D'Orbigny en lo referente a la representación de la arquitectura religiosa y la organización de la plaza de la Misión. El rancho chiquitano, propio de las poblaciones rurales que no se agruparon con los pueblos misioneros, se oculta en este imaginario, e incluso la organización espacial de estos rancheríos, donde no existía plaza ni iglesia, también es inexistente. Incluso aquellos rancheríos de las primeras urbanizaciones misionales, que luego recibieron influencias de los cambios urbanísticos republicanos, tampoco se visibilizan. En este sentido, podríamos afirmar que la tradición premisional urbana y habitacional en las referencias visuales de los chiquitanos se invisibiliza a favor de las vistas de los pueblos misionales.

\section{Idealización del chiquitano}

En las últimas décadas del siglo XIX nos encontramos con un imaginario sobre el indígena chiquitano que deriva del interés del jesuita suizo Josef Spillmann por la obra misionera y en particular por la labor de Martin Schmid en Chiquitos. Es por ello que al analizar el discurso de Schmid mencionábamos el interés por las imágenes que de él surgen no sólo en forma contemporánea, sino también el interés suscitado posteriormente a raíz de la difusión que tuvieron a partir de la obra de Spillman, quien hará una particular lectura de las mismas, que nos revela el pensamiento romántico y exotista europeo de las últimas décadas del siglo XIX. Este jesuita fue historiador (en particular de las misiones jesuíticas), escritor popular y autor de libros para la juventud. En 1876 publicó en forma anónima la vida de Martin Schmid en tres números de la revista "Die katholischen Missionen" (revista creada en 1873 y donde fue editor entre 1880 y 1890), basándose en sus cartas y en la obra del jesuita español y misionero en las Misiones del Paraguay, José Peramás ${ }^{24}$. Su vinculación con el periodismo católico hizo que participara como colaborador de periódicos y revistas católicas como la ya mencionada "Die Katholichen Missionen" y el "Stimmen aus MariaLaach" (creado en 1871).

Luego Spillmann publicará folletos y libros para la juventud donde (re)creará imágenes textuales del Nuevo Mundo en forma fantástica, y en ellas, lo encontramos a Schmid misionando entre los chiquitanos en un panorama idealizado de la evangelización ${ }^{25}$

En sus textos el chiquitano es un "salvaje" al que Schmid pudo "domesticar" cual flautista de Hamelin, ya que una de las imágenes que los mismos recrean es la de los indígenas viviendo en cuevas y Schmid incursionando en la selva para atraerlos con su música hacia la misión.

\footnotetext{
${ }^{24}$ Peramás publicó, luego de la expulsión de la Compañía de Jesús, dos libros con biografías de jesuitas misioneros en el Paraguay y en Chiquitos, siendo la de Schmid la única de esta última región y la más extensa. Las fuentes de Peramás fueron por lo general memorias de personas que conocieron a Schmid, de lo que surge un imaginario casi santificador de la persona de este jesuita.

${ }^{25}$ Entre estas publicaciones sobresalen "En el Nuevo Mundo", cuya Primera Parte referida a las Indias Occidentales y Sudamérica contiene un apartado titulado "P. Martin Schmid SJ, un misionero de los indios del siglo XVIII". También publicaciones en folletos, tituladas "Martin Schmid SA de Baar. Un misionero de los indios del siglo pasado".
} 
Pero lo interesante es que Spillmann también recurre a los elementos visuales para expresar su mirada de la evangelización de Schmid entre los chiquitanos: en "La fiesta del Corpus de los Chiquitos"26, que narra la expulsión de Martin Schmid de Chiquitos, la imagen grabada en la tapa del libro nos revela la "alegría de vivir" del chiquitano en la fiesta religiosa, en el contexto de un paisaje idealizado y en el fondo se observa una iglesia que no se corresponde con la arquitectura de las iglesias barrocas que Schmid había construido, pero que constituye una de las marcas simbólicas más clara de la evangelización, junto a la cruz colgada en el pecho de los indígenas (Imagen 6).

El discurso de Spillmann responde así a una poética singular de la evangelización y la imagen del indígena chiquitano, en particular la que se encuentra en la tapa del libro, se vincula más a los macheteros mojeños con sus imponentes tocados de plumas que a los chiquitanos y sus procesiones del Corpus. Si bien en las diferentes ediciones del libro encontramos imágenes distintas, la tapa suele ilustrarse con la misma imagen, aunque planteando algunas variantes (recortes, enfoques y aproximaciones diferentes a la misma escena festiva). En otras imágenes interiores, la presencia del misionero entre los indígenas

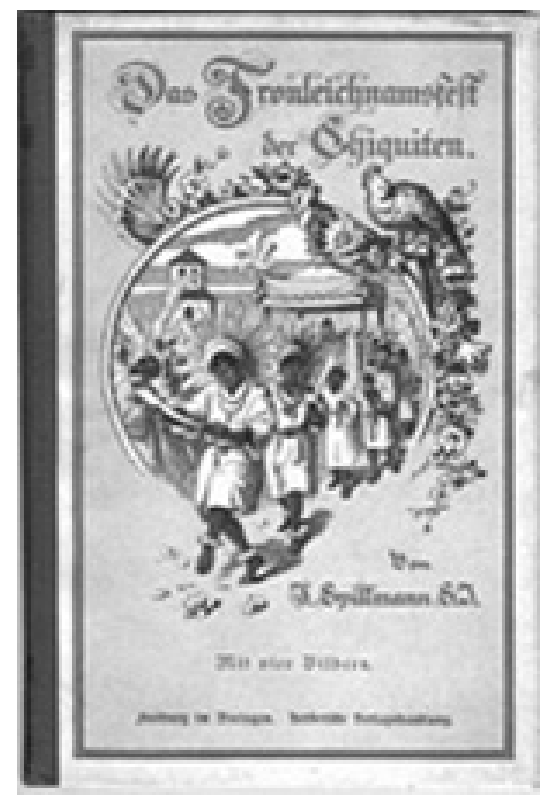

Imágenes 6. Josef Spillmann. Tapa y láminas interiores de "La fiesta de Corpus en Chiquitos", Friburgo, ed. Herder, 1901.

${ }^{26}$ Este libro estaba dedicado a los niños. Hubo numerosas ediciones entre 1902 y 1920, realizadas en Friburgo, Berna, Zurich y Bonn. La primera de Friburgo procede de la editorial Herder, que desde 1894 había comenzado a publicar la primera de una serie colecciones de novelas en castellano escritas por jesuitas a los que la Kulturkampf había dejado sin trabajo en Alemania. Aquella primera colección se llamaba "Desde lejanas tierras”, y también se publicaba en alemán, inglés y francés. 
aparece como la figura testimonial por excelencia de la evangelización lograda. Su presencia certifica el "haber estado alli'" y otorga visibilidad a una idea que los jesuitas remarcaron insistentemente en sus discursos: el estar con y entre los indígenas, "protegiéndolos y educándolos". (Imágenes 7 y 8)
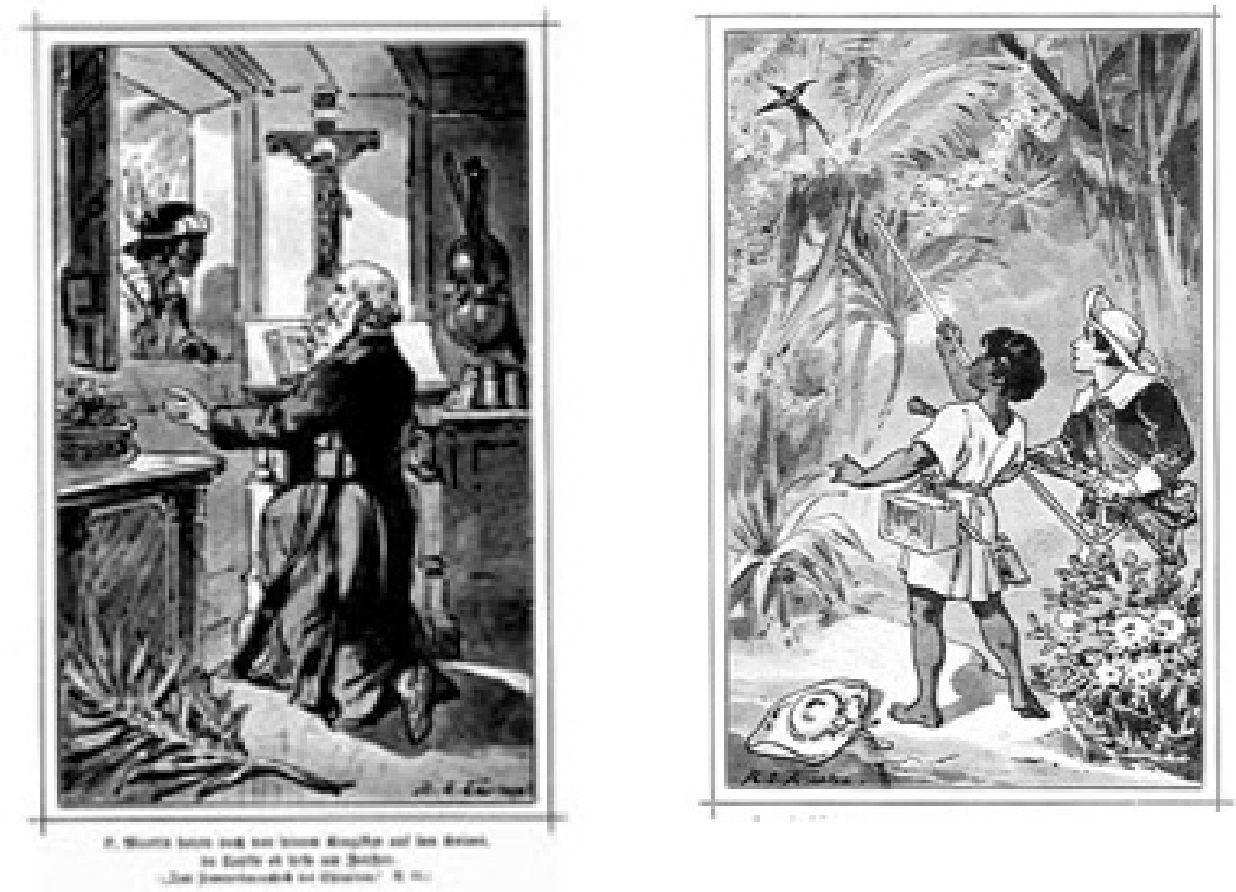

Imágenes 7 y 8. Josef Spillmann. Tapa y láminas interiores de "La fiesta de Corpus en Chiquitos", Friburgo, ed. Herder, 1901.

De lo expresado y siguiento a Starck se puede afirmar que en Spillmann “... el chiquitano corresponde más a los prejuicios europeos que a la realidad indígena”27.

Por consiguiente, esta nueva imagen del chiquitano que tuvo una difusión bastante amplia, en especial en los círculos católicos europeos de fines del siglo XIX y principios del XX, nos revela una recreación de la imagen cristiana con un componente exótico que se deriva del desconocimiento del ámbito y de los grupos que lo habitaban. No obstante, al basarse también en fuentes documentales procedentes de Schmid, esta nueva imagen del chiquitano aparece legitimada por su complementariedad con los argumentos textuales, aún cuando éstos hayan sido ficcionalizados para convertirse en una suerte de "literatura bizarra".

${ }^{27}$ Peter Starck. "De tradiciones españolas y costumbres raras. Ritos religiosos en Chiquitos vistos por europeos." En: Cumbre de las Américas - ProHelvetia. Martin Schmid 1694-1772. Misionero, Músico y arquitecto entre los Chiquitanos. Catálogo de exposición. Cumbre de las Américas - ProHelvetia, Santa Cruz de la Sierra, 1996, p. 44. 


\section{Indigenismo e invisibilidades del chiquitano}

Como en varios de los países latinoamericanos, en las primeras décadas del siglo XX Bolivia estuvo gobernada por una elite liberal que puso en discusión la cuestión indígena en el marco de la definición de la identidad y la constitución de un EstadoNación moderno. Una vez más, el indígena fue utilizado como "objeto" en las polémicas de políticos e intelectuales de la época, y hubo quienes realizaban una defensa idealizada o esperanzadora del indígena mientras que otros lo acusaban de ser el causante de todos los desastres del país.

Lo interesante en este contexto, en relación al imaginario sobre el indígena y su plasmación en representaciones visuales se refiere a dos cuestiones: por un lado, la presencia de un discurso indigenista muy disperso y contradictorio, que valoraba al indígena como un menor de edad e indefenso, se oponía al de la elite conservadora - que tuvo más presencia y difusión en la sociedad en su conjunto-, discurso que consideraba al indígena casi como un ser infradotado e incapaz para la labor pública y política. En el medio, se invisibiliza al indígena chiquitano: no aparecen representaciones visuales, o son escasísimas. Se trata de diferenciarlo del mestizo desde el punto de vista político y social, pero visualmente se invalida lo indígena y se valoriza lo mestizo. Es que al mestizo se lo percibe “... como la base de la nueva y futura comunidad moral, al considerársele híbrido de las culturas europea y andina" 28 , y el "componente más original de la fisonomía boliviana." 29

La cuestión del mestizaje recién comienza a advertirse en la imagen de fines del siglo XIX y principios del XX. Urirorzqui Victoriano expresa que "indio" y "mestizo" eran en la Bolivia de principios del siglo XX, las dos caras de la misma moneda -refiriéndose a la percepción que la elite tenía de ambos grupos. En las representaciones visuales eran por lo general los epígrafes o descriptores de las mismas los que comenzaban a realizar tal distinción, además de los modos en que la fotografía en particular, construía escenas y escenarios para unos y otros.

El hecho de "acholarse", es decir, convertirse en "cholo" 30 , también se hizo eco en la imagen, pero en escasa proporción para la Chiquitanía; son los cholos paceños y cochabambinos los que se visibilizan. Las imágenes difundidas en periódicos y álbumes referidas a la población de la Chiquitanía, siempre se concentraba en el universo indígenacristiano. A ello se suma el hecho de que los grupos mojeños van a tener mayor presencia que el chiquitano en estas representaciones de "lo que queda" del mundo indígena.

${ }^{28}$ Citado por Marta Urirorzqui Victoriano. "El negocio de la política. Indios y mestizos", p. 269. Tomado de Franz Tamayo. Creación de la pedagogía nacional. La Paz, ed. Juventud, 1981 (1907).

${ }^{29}$ Citado por Marta Urirorzqui Victoriano, cit., p. 269. Tomado de Rigoberto Paredes. La política Parlamentaria en Bolivia. La Paz, Ediciones Cerid, 1992 (1908).

${ }^{30}$ Los "cholos" son los indígenas que han abandonado su comunidad, la agricultura y hábitos culturales, radicándose en las ciudades. Son seres que "cabalgan entre dos mundos" y que por su capacidad de articularlos, sin poder dejar atrás el estigma de "casi o ex indios" habitan nuestras sociedades en condiciones de discriminación. Sobre la conceptualización de "cholo”, véase Ximena Soruco. “¿Es posible pensar lo andino más allá de la dicotomía blanco-indio?”. En: América Indígena. Vol. LX, No3, Instituto Indigenista Interamericano, Méjico, jul-sep. 2004, pp. 6-15. 
Dos ejemplos de las primeras décadas del siglo XX nos revelan algunos de estos aspectos: por un lado, el libro "Bolivia", de María Robinson Wright, que podríamos incluirlo dentro de la literatura de viajeros. Las fotografías que se incluyen muestran a indígenas de diferentes regiones (los grupos del Chacoen su hábitat o posando desnudos, las cholas y cholos paceños, cochabambinos y de Potosí, los tembetas radicados en Santa Cruz, los macheteros mojeños), pero el chiquitano no se vislumbra en este panorama visual de Bolivia.

Por su parte, en uno de los Álbumes editados en la época del Centenario de la Independencia de Bolivia, el Departamento de Santa Cruz está representado por la nueva burguesía, el campesinado indígena-mestizo y los indígenas con sacerdotes de la región mojeña (Imágenes 9 y 10). Los indígenas aparecen vinculados a personas u objetos que hacen referencia al mundo misional: sacerdotes que marcan el "estar entre" y "vivir con" los indígenas o instrumentos musicales que refuerzan el imaginario del indígena cristianizado, también a través de la música. Es interesante también aludir al préstamo, circulación y "viaje" de algunas imágenes: la misma imagen de macheteros mojeños que encontramos en el texto de Robinson Wright también se encuentra en el Álbum aludido.

Asimismo, el cholo tiene más presencia en las tomas de los fotógrafos profesionales que el indígena: siguiendo una estética del retrato propia de la elite de la época a la que el cholo busca acercarse en este caso a través de la imagen y de un modo burgués de perpetuar la memoria que lo constituye la fotografía.

Este ocultamiento del chiquitano debe comprenderse quizás en el contexto de una región que era periférica y de poco interés para el Estado Nacional y las jurisdicciones políticas regionales, pero también en el contexto de un discurso de intelectuales que
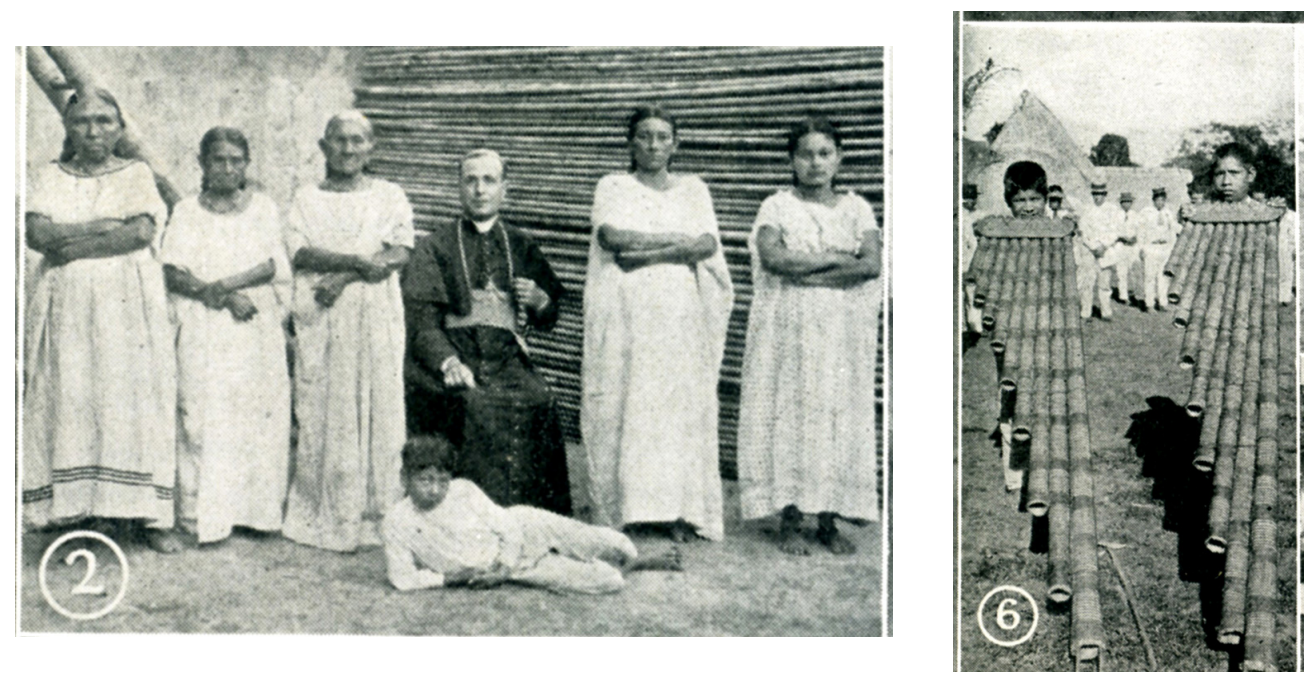

Imágenes 9 y 10. Álbum Bolivia en el Primer Centenario de su Independencia, s/d. 1925 Las imágenes aparecen descriptas como: "Monseñor Carola, rodeado de un grupo de abadesas mojeñas" y "Los bajones, instrumentos de música que se tocan en las grandes ceremonias oficiales y religiosas" 
manipulaba discursivamente la cuestión indígena ${ }^{31}$. Un siglo después de la independencia boliviana, "no se ve" al indígena chiquitano, a la vez que la mayoría de las iglesias jesuíticas están abandonadas, a punto de destruirse muchas de ellas. Ésta constituye otra muestra del escaso interés político por la región. El indígena o mestizo de la región cercana a la Chiquitanía que se visibiliza en esta época es aquel que vive en los alrededores de Santa Cruz.

Ello nos lleva a afirmar que en la primera mitad del siglo XX hay una escasa presencia de las representaciones del indígena chiquitano, coincidente con la exclusión social y política que esta población sufrió en esta época, legitimada incluso por los intelectuales. Durante este periodo, es posible advertir una negación de la diferencia cultural como parte de la identidad boliviana y una referencia "parcial" (y hasta "funcional" a la política) del indígena, invalidando su presencia como constructor de esa identidad.

\section{El indígena como anexo de visibilidad}

Promediando la mitad del siglo XX, las imágenes que se habían anclado en la conciencia social boliviana respecto del indígena chiquitano lo vinculaban al mundo jesuítico y por lo tanto era un actor social que había quedado cien años -o más- congelado en la historia y en el imaginario social. Era más bien el pasado y no el presente lo que se percibía.

Hacia 1944 la Chiquitanía comienza un proceso diferente de visibilización de su patrimonio y su gente, como consecuencia de la labor de Plácido Molina quien, más allá de su labor de funcionario del Estado, inició una lucha por rescatar el patrimonio en ruinas de la región. ${ }^{32} \mathrm{El}$ registro fotográfico constituyó la etapa inicial de su proyecto y el origen del Archivo Fotográfico de Chiquitos. Las imágenes de este relevamiento, obtenidas por el mismo Molina y por el cinematógrafo alemán Hans Ertl, fueron utilizadas contemporáneamente como respaldo de testimonios verbales, ilustraciones de artículos de prensa y opúsculos, acompañamiento de circulares y memoriales, etc., y constituyen un corpus particular de gran interés en la reconstrucción del imaginario del indígena chiquitano $^{33}$.

En primer lugar, es necesario destacar que el interés estaba en el relevamiento y documentación visual de la arquitectura de las antiguas misiones jesuíticas, y por lo tanto, los indígenas aparecen en este proyecto a modo de anexo, expresando un escaso o nulo interés en documentar las formas de vida de los grupos indígenas. Incluso en la publicación de gran parte de este archivo, también aparece en primer plano el universo arquitectónico-patrimonial y en segundo plano "Los hombres" ${ }^{34}$. Pero aún operando como anexo, la representación del indígena chiquitano hace una reaparición de la que no gozaba desde la primera mitad de siglo.

\footnotetext{
${ }^{31}$ La elite dirigente fundamentó el atraso boliviano en una cuestión de "raza" (en alusión a la población indígena) y de geografia.

32 Sobre los objetivos, avatares y resultados de este proyecto véase Plácido Molina. "Homenaje y testimonio". En: Pedro Querejazu (ed.). Op. cit., pp. 229-249.

33 Ibidem.

${ }^{34}$ Ibidem, pp. 19-227.
} 
La sección "Los hombres" de este archivo consolida la imagen del chiquitano evangelizado: las fotos refieren a las fiestas patronales, retratos de indígenas portando imágenes religiosas o tocando instrumentos musicales (recordemos que la música fue uno de los elementos centrales en la evangelización jesuítica, y de gran importancia en la Chiquitanía), imágenes procesionales, conjuntos musicales ejecutando piezas en la iglesia o posando para el fotógrafo con sus instrumentos. Pero también se encuentran retratos y "escenas étnicas" 35 ; estas últimas ocupan un lugar pequeño pero de gran importancia y se refieren principalmente a actividades de mujeres indígenas (aguateras transportando tinajas, otras moliendo maíz o tejiendo en telar, e incluso en máquinas de coser), pero también hombres realizando esterillas, pescando con red, descortezando troncos, etc. El trabajo de los hombres en el campo, tanto en ganadería como en agricultura o abriendo picadas en la frontera, en el contexto de una naturaleza prodigiosa, completan a grandes rasgos esta colección. En su conjunto, estas imágenes constituyen una reaparición del indígena chiquitano en su contexto, con una focalización especial en su herencia misionera y su cotidianeidad.

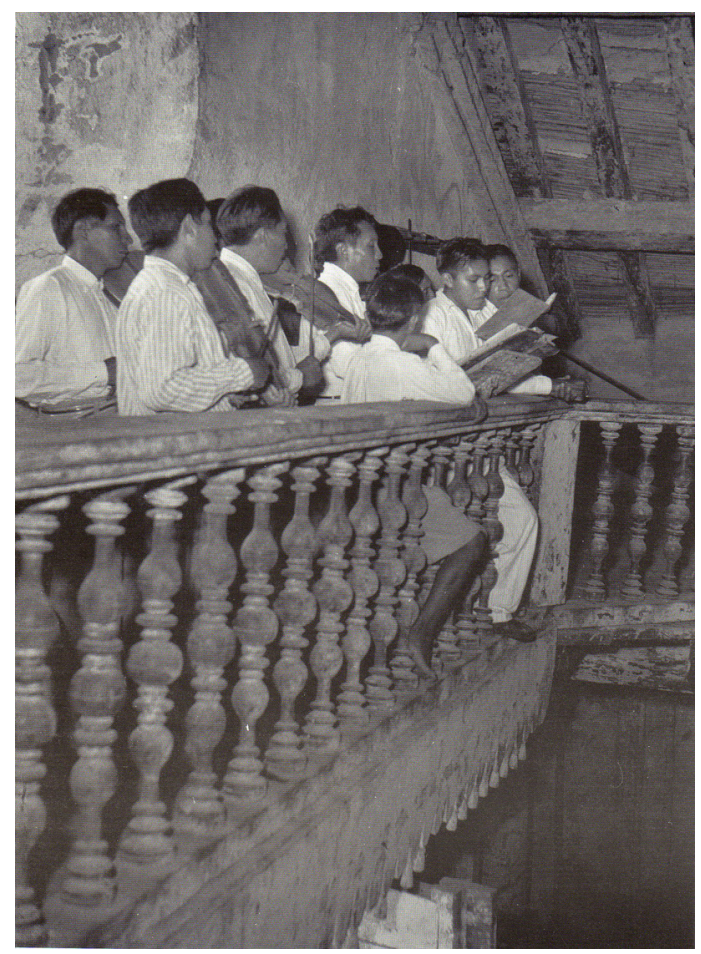

Imagen 11. Hans Ertl. "San Rafael. Los solfas cantando en latín leyendo la música escrita, en una ceremonia sin sacerdote". 1951 Archivo fotográfico de Chiquitos

\footnotetext{
${ }^{35}$ Por "escena étnica" entendemos al procedimiento fotográfico donde sujeto y objetos entran en una dinámica de relaciones espaciales, buscando muchas veces generar una atmósfera no contaminada por la presencia de la cámara. Los representados parecen estar realizando parte de sus actividades cotidianas en medio de las cuales el fotógrafo, supuestamente, los ha sorprendido para fijarlos en una imagen.
} 
El hecho de ser un "anexo" del patrimonio arquitectónico no desmerece el valor de las imágenes, sino que indica la intencionalidad con la que fueron obtenidas y el contexto en que la producción se realiza. Incluso, aquellas en las que el interés fue la documentación del patrimonio arquitectónico y artístico pero donde también se hace presente el indígena, contribuyen a consolidar el imaginario evangelizador. Una imagen sobresaliente en tal sentido es la tomada por Ertl de un grupo de mujeres orando en la Iglesia de San Rafael (Imagen 12). La toma realizada desde un punto alto, connota el control espacial y la presencia de un grupo de mujeres arrodilladas que son vistas de espalda. Todo ello en el contexto de un espacio austero pero con una fuerte presencia de símbolos, sintetizan la religiosidad chiquitana y la vivencia de los valores cristianos, convirtiendo a la imagen en un legítimo testimonio de la evangelización lograda.

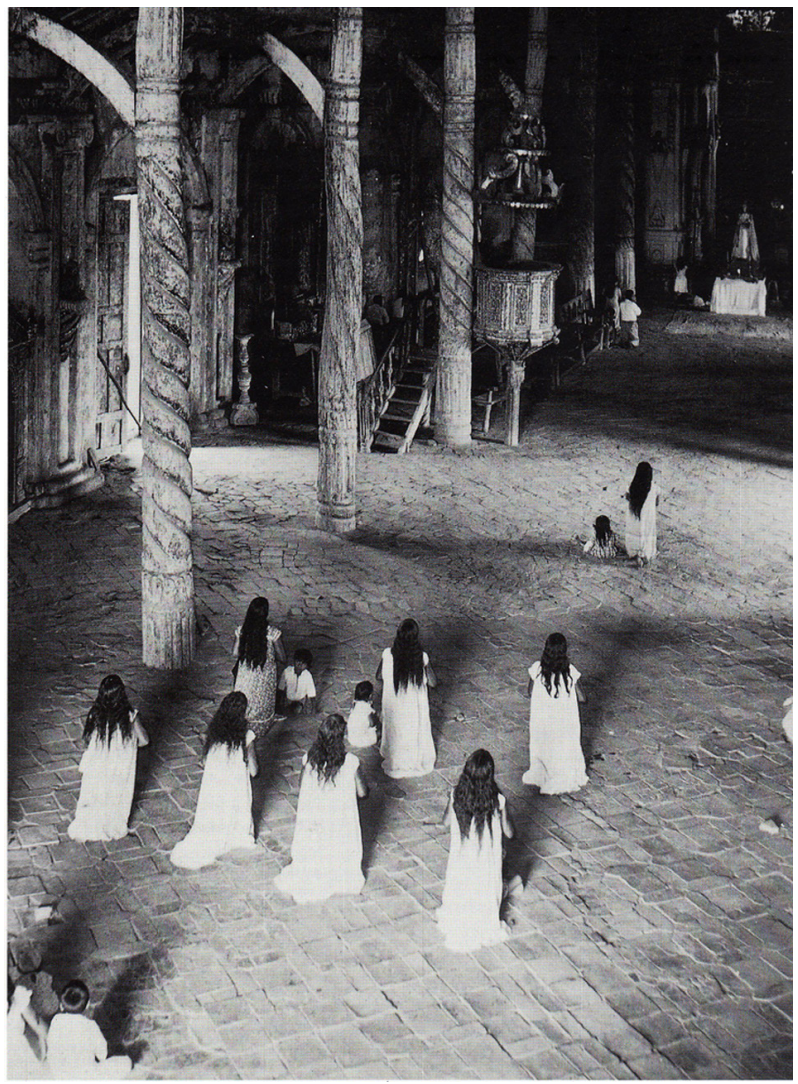

Imagen 12. Hans Ertl. "Mujeres rezando en la iglesia de San Rafael”. 1951 Archivo fotográfico de Chiquitos

Otras colecciones fotográficas realizadas en la segunda mitad del siglo XX continúan con esta imagen que hace énfasis en lo patrimonial y en la que -pese a que también pareciera respetarse parcialmente cierta "intangibilidad" de la cultura indígena- la 
arquitectura se erige como elemento identitario y como referente de la herencia misionera. Entre ellas, las imágenes logradas en la expedición por Chiquitos realizada por el jesuita suizo Féliz Plattner y el fotógrafo Albert Lunte. ${ }^{36}$

\section{A modo de epílogo. La "esplendorosa Chiquitanía"}

Imagen, otredad, memoria, espacio, se conjugan en este trabajo, donde no queda ajeno el concepto de "frontera": por un lado, desde el papel desempeñado en este territorio misionero y estas sociedades en el mundo colonial y su posterior situación en la formación de los respectivos estados nacionales; pero especialmente, desde la consideración de fronteras culturales, religiosas e ideológicas.

Hemos podido advertir las continuidades y rupturas en la construcción de memorias visuales en dos viajeros que con diversos intereses recorrieron la Chiquitanía, además de otras regiones bolivianas en el caso de Mercado y de otros Estados nacionales en el caso de D'Orbigny. Visualmente, el indígena misionero es en ambos casos, un elemento central en este imaginario, que aún Mercado visibiliza (si bien en ciertas oportunidades se refiere a Mojos, en su discurso escrito alude explícitamente al caso chiquitano).

A partir de estos dos discursos considerados como casos paradigmáticos para el análisis propuesto, es posible afirmar que la identidad y la memoria del indígena chiquitano se fueron construyendo en relación con la Misión, y durante gran parte del siglo XIX estuvo vinculada a la evangelización. Los íconos elegidos para materializar este imaginario no siempre fueron explícitos (salvo la presencia de la cruz), pero tanto la vestimenta como el peinado constituyeron -entre otros-importantes íconos que actuaron indirectamente como referentes de la evangelización.

Pese a la homogeneidad con el que se representaba al chiquitano, en la obra de Mercado advertimos ciertos pliegues, a través de los cuales se alude a los bordes étnicos y al mestizaje, pero en el núcleo del imaginario estos aspectos cumplen un papel secundario, a la vez que se silencian las protestas étnicas y sociales, como así también se ocultan las imágenes de los indígenas no evangelizados.

Las imágenes del siglo XIX se convierten en escenas de poder e identidad atribuida externamente, en estrategias para la construcción de memorias visuales. A tal punto que el imaginario de D'Orbigny del indígena evangelizado se reactualiza a mediados del siglo $\mathrm{XX}$, y muchas de las mismas imágenes de este naturalista seguirán teniendo una circulación importante en postales y estampillas en Bolivia.

Hacia fines del siglo XIX nos encontramos con un imaginario del chiquitano (re) creado por Spillmann que se aparta de lo narrativo-testimonial para convertirse en una idealización del mundo misional a partir de la obra de Martin Schmid. El indígena queda algo relegado en esta literatura, donde creación y justificación documental pretenden sostenerse mutuamente, pero que argumentalmente se convierten en una abstracción idealizada de la labor misionera e incluso en una ficcionalización del mundo de la Misión.

${ }^{36} \mathrm{Al}$ respecto, véase Eckart Kühne. "Colecciones fotográficas antiguas en archivos eclesiásticos”. En: Revista Cultural del Banco Central de Bolivia. Año VIII, No27. La Paz, 2004, pp. 13-22. 
Si bien el siglo XX marca, en sus primeras décadas, una etapa de gran discusión política, social y académica sobre el indígena en Bolivia, como contrapartida, existe una importante invisibilidad del mismo. Los fotógrafos profesionales se ocupan principalmente de retratos de la élite, de mestizos y de indígenas que viven en las ciudades, todos ellos siguiendo el canon de representación del retrato burgués. El chiquitano encuentra escasa representación en este contexto. Su ausencia en textos conmemorativos del Centenario suponen, ideológicamente, no sólo su negación contemporánea, sino también su escasa consideración en los últimos cien años de historia republicana.

Esta permanencia de una identidad lejana y la negación de una identidad actual responden a una idea de inmovilidad identitaria, en desmedro de una identidad en permanente construcción.

Es recién a partir de la segunda mitad de siglo cuando la imagen del chiquitano comienza a tomar fuerza, aunque anexado a la cuestión del patrimonio arquitectónico y artístico. Ello derivará en dos cuestiones: por un lado, en la nueva presencia de visibilidades chiquitanas, pero también, en el hecho de ocupar un lugar secundario en los intereses de la Chiquitanía, donde lo patrimonial será lo prioritario. Hoy, cualquier referencia a la Chiquitanía, presenta primero las iglesias, la música, y por último al indígena. Todo ello en el contexto discursivo de una "esplendorosa Chiquitanía". Y ello no responde a opciones estéticas, sino a intereses e ideologías que van más allá de la imagen, o más bien, que se traslucen en la presencia o ausencia, en los develamientos u ocultamientos de las imágenes.

Si la Chiquitanía es una región homogénea y cristiana, una nación esplendorosa, como la mayoría de las representaciones que surgían de la historiografía querían transmitir, lo es porque hay en ella tantos pliegues y matices culturales como infinitas maneras de imaginarla, de mostrarla, de otorgarle presencia o de negarla, según variados y disímiles intereses sociales, políticos, estéticos, etc.

\section{Bibliografía}

Albarracín, Juan. Una visión esplendorosa de Bolivia: las exploraciones de Alcides d'Orbigny en Bolivia. La Paz, Plural, 2002.

Albó, Xavier, Greaves, Tomás y Godofredo Sandoval. Chukiyawu. La cara aymara de La Paz. Cabalgando entre dos mundos. La Paz, CIPCA, Vol III, 1983.

Arze Aguirre, René (comp.). El naturalista francés Alcide Dessaline d'Orbigny en la visión de los bolivianos. Institut français d'etudes andines. IFEA - Plural, Embajada de Francia en Bolivia,

Bach, Caleb. Melchor María Mercado, pintor. Perspicaz colorista de costumbres. Américas, 2001. Bertrand, Michel y Vidal, Laurent (dir.). À la redécouverte des Amériques. Les voyageurs européens au siècle des indépendances. Presses Universitaires du Mirail, 2002.

Burke, Peter. Visto y no visto. El uso de la imagen como documento histórico. Editorial Crítica. Barcelona, 2001.

Castoriadis, Cornelius. La institución imaginaria de la sociedad. Buenos Aires, Tusquets, 1993. Cumbre de las Américas - ProHelvetia. Martin Schmid 1694-1772. Misionero, Músico y arquitecto 
entre los Chiquitanos. Catálogo de exposición. Cumbre de las Américas - ProHelvetia, Santa Cruz de la Sierra, 1996.

D‘Orbigny, Alcides. Viaje a la América Meridional. Buenos Aires, Editorial Futuro, 1945.

Dubois, Philippe. El acto fotográfico. De la recepción a la representación. Ediciones Paidós. Barcelona. Santiago, 1986.

Edwards, Elizabeth. Anthropology \& Photography. 1860-1920. London, Yale University Press, 1992. Fellner, Stefan. "Ya que entiendo de música. Principios musicales en la arquitectura de Martin Schmid". En: Cumbre de las Américas - ProHelvetia. Martin Schmid 1694-1772. Misionero, Músico y arquitecto entre los Chiquitanos. Cit., pp75-88.

Garreta, Mariano J. "Ciencias antropológicas". En: Garreta, M. y Belelli, C. (comp). La trama cultural. Buenos Aires, Ediciones Califaz, 2001.

Giordano, Mariana. Discurso e imagen sobre el indígena chaqueño. La Plata, Ediciones Al Margen, 2004.

. "Escenarios y escenas étnicas en la fotografía misionera. Imaginario franciscano del Chaco boliviano.” XXVI Encuentro de Geohistoria Regional. Resistencia, IIGHI-CONICET, 2007, pp. 221-228.

Gunnar Mendoza L. "Vocación de arte y drama histórico nacional en Bolivia: el pintor Melchor María Mercado (1816-1871). Un precursor”. En: Melchor María Mercado. Album de paisajes, tipos humanos y costumbres de Bolivia (1841-1869). Cit.

Kühne, Eckart. "Colecciones fotográficas antiguas en archivos eclesiásticos”. En: Revista Cultural del Banco Central de Bolivia. Año VIII, No27. La Paz, 2004, pp. 13-22.

- "Martin Schmid y la misión de Chiquitos". En: Cumbre de las Américas -

ProHelvetia. Martin Schmid 1694-1772. Misionero, Músico y arquitecto entre los Chiquitanos. Cit., pp. 19-30.

Mercado, Melchor María. Álbum de paisajes, tipos humanos y costumbres de Bolivia (1841-1869). Banco Nacional de Bolivia, Sucre, 1983.

Querejazu, Pedro (ed.). Las Misiones Jesuíticas de Chiquitos. La Paz, Fundación BHN, 1995.

Rivera Cusicanqui, Silvia. "Secuencias iconográficas en Melchor María Mercado.” En: Travaux de l'IFEA 102, La Paz, 1997, pp. 147-168. . Invisible Realities: internal markets and subaltern identities in Contemporary Bolivia. Malasia, Vinlin Press Sdn Bhd, 2005.

Santamaría, Daniel. "Los métodos misioneros de los Jesuitas en Chiquitos". En: Cumbre de las Américas - ProHelvetia. Martin Schmid 1694-1772. Misionero, Músico y arquitecto entre los Chiquitanos. Cit., pp. 25-30.

Sebastián, Santiago. "El indio desde la iconografía". En: AA.VV. La imagen del indio en la Europa Moderna. Sevilla, CSIC-Escuela de Estudios Hispanoamericanos, 1990, pp.433-455.

Soruco, Ximena. “¿Es posible pensar lo andino más allá de la dicotomía blanco-indio?”. En: América Indígena. Vol. LX, №3, Instituto Indigenista Interamericano, Méjico, jul-sep. 2004, pp. 6-15. Strack, Peter. "Ritos religiosos en Chiquitos vistos por europeos". En: Cumbre de las Américas ProHelvetia. Martin Schmid 1694-1772. Misionero, Músico y arquitecto entre los Chiquitanos. Cit., pp. 39-46.

Tomichá Charupá, Roberto. La primera evangelización en la Reducción de Chiquitos, Bolivia (16911767). Protagonistas y Metodología misional. Roma, Pontificia universitas Gregoriana, 2000. Urirorzqui Victoriano, Marta. "El negocio de la política. Indios y mestizos en el discurso de la elite 
boliviana, 1900-1920”. En: Del Pino, Fermín y Lázaro, Carlos. Visión de los otros y visión de sí mismos. Madrid, CSIC, 1995, pp.251-272.

Von Küugelgen Kropkinger, Helga. “El indio: ¿bárbaro y/o buen salvaje?”. En: AA.VV. La imagen del indio en la Europa Moderna. Cit., pp. 457-487.

\title{
Resumen
}

Los procesos de construcción de alteridades pueden ser (re)construidos de diferentes formas, una de ellas es a través del análisis del universo visual y textual referido a ese "otro". La intención de este trabajo es analizar la construcción de un universo imaginario sobre el indígena chiquitano, centrándonos en imágenes producidas luego de los procesos de independencia americanos en los siglos XIX y la primera mitad del siglo XX. Analizamos los modos en que se ha nominado y representado al indígena chiquitano, la construcción, permanencia y pliegues de una imagen homogeneizadora del "chiquitano evangelizado" procedente de la época colonial pero que ha permeado en los discursos y proyectos políticos y religiosos. En tal sentido, indagamos en las potencialidades de la imagen como discurso legitimador del texto escrito, enfatizando tanto en su presencia (visibilidades) como en su ausencia (ocultamiento), en otras palabras, en lo "visto y no visto"

$$
<\text { Imaginario }><\text { Indígena chiquitano }><\text { Visibilidades }><\text { Ocultamientos }>
$$

\begin{abstract}
The process of alterities construction can be (re)constructed in different ways, one of them is through the analysis of the universe visual and textual about the "other". This paper attempts to analyze the construction of an imaginary universe about Chiquitano indians, focusing on images produced after the independence processes in the nineteenth and the first half of the twentieth century. We analyzed the ways in which the Chiquitano Indians were nominated and represented, and the construction, permanence and folds of a standardized image of "Chiquitano evangelized" coming from the colonial times which is still present in speeches and political and religious projects. In this sense, we propose to work on the potential of the image as way of legitimize the written text, emphasizing on the "seen and not seen."
\end{abstract}

$<$ Imaginary $><$ Chiquitano indigenous $><$ Visibilities $><$ Concealment $>$ 